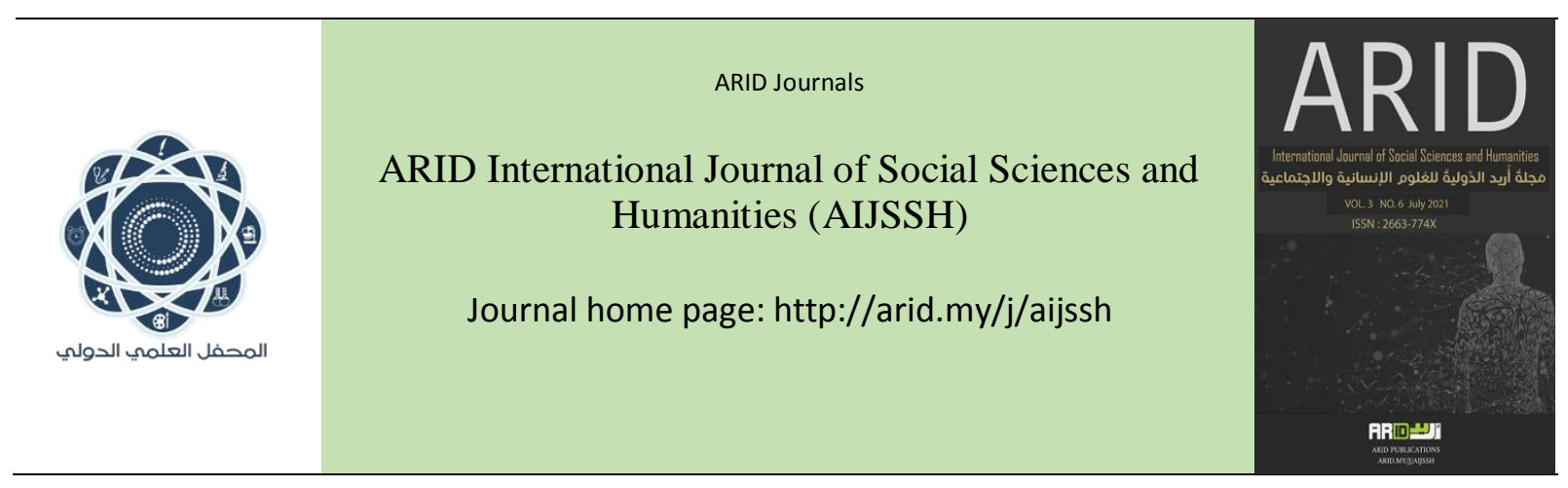

$$
\begin{aligned}
& \text { مَجلةُ أُريد الدَّوليُُّ للعُلومِ الإنسانية والإجتماعية } \\
& \text { البجلد الثالث ،العدد السادس، تموز } 2021 \text { م }
\end{aligned}
$$

\title{
Teaching Literature/Studying Literature in Literary Pedagogy and Literary Theory
}

\author{
Abdel-Fattah M. Adel \\ Department of English, College of Arts, University of Bisha, Saudi Arabia \\ تدريس الأدب ودراسة الأدب بين طرق التدريس والنظرية الأدبية \\ عبد الفتاح محمد عادل \\ قسم اللغة الإنجليزية، كلية الآداب، جامعة بيشة، السعودية
}




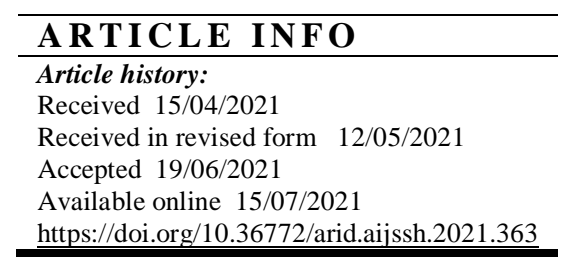

\begin{abstract}
Literary studies, in its two sides: teaching literature and studying literature, have suffered from a split in the profession between literary pedagogy and literary theories. A survey of the experience of some famous scholars, who have tackled, this issue in their writings, is conducted to pinpoint the neglect in the part of people specialized in literary studies of the practical side of their work. Two points of convergence between literary pedagogy and literary theory are discussed. Thus, the first one presented two cases in which literary pedagogy was highly influenced by the ideas of two major shifts in critical theory: the formalist tendency of New Criticism and the reader-oriented tendency of the reader response approach. The second one discussed the efforts of the American educationalist and theorist Louise Rosenblatt in providing a theory of reading literary works in the light of what takes place in literature classrooms. The conclusions derived from this discussion lead to recommendations concerning the importance of making teaching of literature one of the academic interests and student preparation in departments of literature.
\end{abstract}

Key Words: teaching literature, literary pedagogy, literary theory, literary criticism, Louise Rosenblatt. 


\section{| (لملنص}

عانت الدر اسات الأدبية، من جهتيها: تدريس الأدب ودر اسة الأدب، من انقسام في المهنـة بين طرق التداء التدريس الأدب و النظريات الأدبيـة.

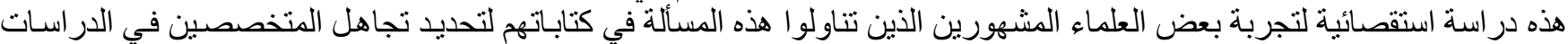

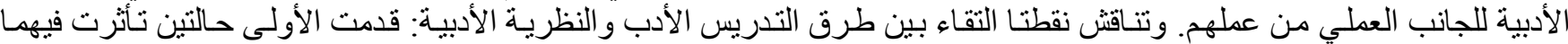

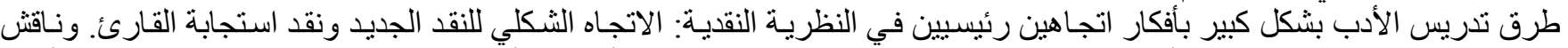

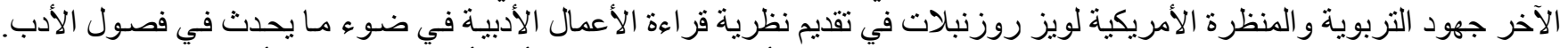

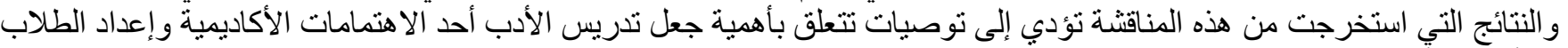
في أقسام الأدب.

الكلمات المفتحية: تدريس الأدب ـ النظرية الأدبية ـ النقد الأدبي ـ لويز روزنبلات 


\section{Introduction.}

Literary studies, of its both sides: teaching literature and studying literature, have suffered from what Carolyn Allen calls the "unfortunate split" in the profession between literary pedagogy on the one hand and literary criticism and theories on the other. [1, p.17] This seems rather strange when one considers the fact that most of those who work in literary criticism and theory teach literature. Moreover, the teaching situation provides literary theorists with a good context for deriving and applying their critical theories. In schools, colleges, and universities, they can find what Gerald Graff describes as the "conscripted clientele" of literature. [2, p.82]

Louise Rosenblatt represents one of the valuable attempts to bridge this gap by explaining the theoretical basis of what was going on inside the classroom. She started to question the assumptions of the traditional approaches to teaching literature in the light of her literary theory. The pedagogical implications in her theory are numerous; moreover, in the light of the application of her theory in the classroom, she modified and re-theorized many aspects of her theory. [3, p.50] She was after "a broader theory of literature, learning, and instruction" that will help to realize the potentialities of literature education. [4, p.63] She considered teachers of literature "literary critics" who could help students make more out of their transaction with literary works. Teachers, however, could not do that without being able to reflect more deeply on the dynamics of reading. [5, pp.39-40]: what George Levine calls "some very self-conscious theorizing." $[6, \mathrm{p} .14]$

This paper outlines the methods of teaching literature as explicated in literary pedagogy and the development of these methods. This development will be traced in the theories and methods of reading and analyzing literature presented in modern literary theory. Louise Rosenblatt will be discussed in this respect as one of the rare literary theorists who have been on both sides: literary pedagogy and literary theory. She has presented one of the famous theories of reading literature: the transactional theory or reading; and she is one of the most cited theorists in literary pedagogy, the source of valuable insights in 
teaching literature since the 1960s [7, p.152], and according to Pugh (2005), Rosenblatt was the best to explicated reader-response ideas as a pedagogical as well as a critical stance. [8]

\section{Teaching Literature/Studying Literature: A Split in the Profession}

In "Interdisciplinary Research: Putting the Methods under the Microscope," David Robertson and his colleagues assert that the core of interdisciplinarity is the encounter between different conceptual structures [9] The boundaries between disciplines can be transcended only when a common language is developed, along with shared practices and methods, in order to facilitate a shared conceptual framework. Literature education can get into interdisciplinary studies with other sciences, David S. Burk reports on an interdisciplinary unit involving literature, math, science, and other disciplines. [10] Literary criticism, as well, can get into with other disciplines like psychology and sociology; Interdisciplinary Literary Studies is a journal dedicated for such studies. ${ }^{1}$

However, one wonders if we need to do such encounters when issues related to literary criticism and literary pedagogy are involved. Are there two disciplines in the first place, or it is a division within one discipline? Do we need to develop such a "common language"? Are not "reading," "reader," text," "interpretation," etc., key terms in both fields? Are not the "methods" applied in literature education usually taken from literary criticism? Is not "practice" in literature education supposed to be the best context from which generalization and theorizing start? What is missing is the act of crossing the boundaries between the two divisions of the profession.

This fact led George Levine to refer to the profession of "English studies" as "a nation divided" entitling his article that speculates this issue "The Two Nations" (2001] Levine highlights "the split between our work as teachers and our work as scholars." A faculty gets hired to teach literature, but teaching literature is not usually the primary focus of his research. When a faculty, argues Levine, says "My work," he/she usually means research and writing (dedication to research and criticism) as opposed 
to work in the classroom or service to department or university (dedication to teaching). [6, pp.7-9] Levine concludes this point saying:

We were trained to live in two nations: the pedagogues, who occasionally also write about teaching, and the literary scholars, who don't. If those scholars don't want the language of pedagogy to fall into the wrong hands they need to find ways to make the teaching of all students interesting as well. [6, p.17]

One of the issues that highlight this split in the United States is the overlap in membership in two famous organizations: The Modern Language Association (MLA) and the National Council of Teachers of English (NCTE). [6, pp.9-10]

Although the profession has already begun to recognize that literary scholarship can no longer be disentangled from teaching, the gab cannot be bridged by mere recognition and intention. In 1997, the editorial board of PMLA (the journal of the Modern Language Association) decided to publish an issue on the teaching of literature. Levine studied this experience and found the result "interestingly symptomatic" of the culture of the two nations. A large submission of manuscripts on teaching was received, however, most of them could not address "the fundamental problems that the current state of teaching in the university produces." The MLA editorial board could not find more than two that were "up to the standards of PMLA scholarship." The experience proved that few could meet the scholarly demands of PMLA and discuss teaching at the same time. This incident can be considered as an indication of "a discipline-wide, thoroughly systemic failure to engage with pedagogy," exposing "literary scholarship and scholarship of pedagogy as at odds." The PMLA effort demonstrated "the weakness of the profession's commitment to teaching in the very act of emphasizing that commitment. The teaching/research split, as a result, continues to hurt the profession.” [6, pp.10-11] 
Levine rejects the reductionist attitude that considers teaching literature something obvious that requires less effort to be mastered. He insists that teaching literature is a subject, and a difficult one. It requires scholarly and critical sophistication that he calls "some very self-conscious theorizing." The necessities of the classroom will have their effect:

But beyond the questions that ought to feed any serious critic's sense of what doing literature might mean, there are questions about the relation between such sophistication and the necessities of the classroom: what, how, and when are students most likely to learn? The reality of engagement with students makes the already difficult questions about the nature of literature and literary study even more difficult than they seem at the level of high theory, in graduate seminars, at international conferences. [6, p.14]

Levine concludes that all these "incoherences" have to be resolved by the people of the profession themselves, "on our own hook," by integrating the "full range of teaching into our ways of thinking about literature and culture." [6, p.18]

Michael Bérubé tackles this problem in the profession when he investigates the issue of employment for English major graduates. In "The Employment of English: Theory, Jobs, and the Future of Literary Studies" (1998), Bérubé shows how in departments of English some started to complain that academic criticism is too esoteric and too politicized that any kind of criticism inevitably positions itself as "superior" to its object [11, p.viii] In their sense of detachment from the market, graduates of literature started to ask "whether literary criticism loves literature." [11, p.7] He cites William Cain reporting:

When a graduate student leaves the university with a Ph.D., he or she has little idea of what it means to read a text carefully or how to convey to students the skills needed to perform this 
activity. Nor is he or she prepared to make the choices required when designing courses and curricula for undergraduates. [11, p.11]

Bérubé refers to what he calls the "bad faith" held at even big universities that their graduate students are simply students and not also "employees." [11, p.37]

The issue of what should be taught to students of literature and the nature of this study is not something simple and obvious as it looks. For Northrop Frye, literature is not a "subject" of study, but an "object" of study. [12, p.11] Paul Hawkins considers that one of the most important conclusions Frye arrives at in his famous book The Anatomy of Criticism, is that "teaching literature is actually the teaching of criticism of literature" and as a result teaching literature should "aim at developing in the student a fluency in terms, categories, and critical approaches that permit a vision of the coherence of literature.” $[13$, p.131]

Jane Tompkins was one of the first scholars to open up the question of the general lack of preparation for teaching to literature graduates in her essay "Pedagogy of the Distressed" (1990) which she developed latter in a book: A Life in School: What the Teacher Learned (1996). Before she explains in her essay what she calls "the politics of the classroom," Tompkins recalls how her early experience in teaching was "exactly like sex": "something you weren't supposed to talk about or focus on in any way, but that you were supposed to be able to do properly when the time came." [14, p.655] After a considerable experience, she discovered that

what we do in the classroom is our politics ... There is no substitute for practice ... A kinder, more sensitive attitude toward one's own needs as a human being, in place of a desperate striving to meet professional and institutional standards of arguable merit, can bring greater sensitivity to the needs of students and a more sympathetic understanding of their positions, both as workers in the academy and as people in the wider world. [14, p.660] 
In her book, Tompkins recalls her experience of beginning teaching at Yale. Nothing in that experience shed any light on what classroom teaching was about:

When I asked the assistant professor I was apprenticed to for advice about the two lectures I was slated to give ... he said 'stay close to the text.' Well, that was Yale's answer to every question about literature, and I knew it already. But as a teaching strategy, it left me groping.

Now, she reflects,

I'm amazed that my fellow Ph.D.s and I were let loose in the classrooms with virtually no preparation for what we would encounter in a human sense ... If only I'd known, if someone I respected had talked to me honestly about teaching, I might have been saved from a lot of pain. ${ }^{2}$

Elaine Showalter, one of the founders of feminist literary criticism, wrote a book about her experience in teaching literature. In the preface to Teaching Literature (2003), she recalls her surprise that suddenly in 1963, when she started to take a job in teaching; she was called "Teacher Elaine." She thought that she was not much of a teacher then: "although I had been exposed to a lot of professors, lectures and seminars, no one had ever talked about what might be involved in teaching literature and few appeared to have given it much consideration." [15, p.vi] The first chapter in her book is on "The Anxiety of Teaching;" she outlines seven types of anxiety related to teaching literature; the first of which is "lack of pedagogical training" along with "isolation, stage fright, the conflict between teaching and publication, coverage, grading, and student or peer evaluation." [15, p.4] Thrown into one of the most demanding occupation, Showalter found out, most tenured professors picked up teaching through painful experience. She refers to the experience of many literature professors who have gone through tough times when they started teaching literature at college levels. ${ }^{3}$ One of those is Norman Maclean who writes that the only advice he ever received about teaching was to "wear a different suit every day 
of the week!." [15, pp.4-5] She concludes that "the pedagogy of the depressed" described by all those teachers is still all too frequent because many still think that good teaching is a natural complement of scholarly research. $[15$, p.7]

\section{Literary Theory/Literary Pedagogy: Points of Convergence}

The first section of this article pinpointed the split in the profession as a result of the lack of interest professors of literature have regarding how to teach literature in comparison to their extensive work on literature as a body of writings. However, studies that have traced the development of the methods of teaching literature are always connected with the development of literary criticism and literary theory. Carter and Long's Teaching Literature (1991) was published in a Longman's series of handbooks for language teachers. Among the many chapters dealing with methods and strategies for reading literature, the authors had to dedicate a chapter on the theories of reading literature tracing the development of literary theory. Elaine Showalter not only used the same title for her book, Teaching Literature (2003), but also outlined the development of the theories underlying teaching literature. This leads to the conclusion that there are some points of convergence in which literary teaching methodology has been guided by literary theory and this section will outline two of these points. However, it is rare that classroom practice has been used to direct literary theories due to the neglect on the part of researchers of the importance and relevance of this practice. Louise Rosenblatt presented one of those rare attempts and this will be discussed in the next section.

The two main points of convergence in which literary theory laid the foundations for a teaching methodology of literature are the formalist tendency of New Criticism and the reader-oriented tendency of the reader response approach. Both tendencies are considered groundbreaking developments in literary theory, and they have had their considerable percussions on literary pedagogy. 


\subsection{New Criticism:}

The first half of the twentieth century witnessed domination of the New Critical approach to the study and the teaching of literature. However, the moralistic tradition, which preceded New Criticism, was still with considerable force in dealing with the literary works in literature classrooms. Consequently, the literature curriculum was characterized by "an analytical and moralistic frame." [16, p.2] Under the "spell" of this combination, literature teachers were taught literature, and in this way they taught it. ${ }^{4}$

Nicholas J. Karolides identifies several assumptions underlying these traditional approaches of teaching literature:

... (a) the author's intention is the key to ascertaining what the work means and this meaning can be identified; (b) the text is an object that has a determined meaning of its own; (c) the text can be analyzed through objective, close scrutiny of its formal structure and techniques to establish the meaning. Furthermore, it is often assumed that there is but one meaning. [17, p.28]

The reader's role, notices Karolides, was either neglected, or omitted entirely. [17, p.28] There was no room in these approaches for the personal experiences of the readers as if all people had led the same sorts of lives, read the same books, and shared their views on most things. These approaches started from an assumption of a commonality of experience in readers. [5, p.29] Thus, they missed what Clem Young calls "the triad of relationships involving readers, texts, and teachers" which is central to any understanding of the ways in which readers are made and modified in literature classrooms. [18, p.7]

Richard Beach shows how literature education "was based on the desire to present didactic lessons regarding good behavior and to impart the virtues of literary" classics. The method used aimed at emphasizing the teacher's privileged interpretation at the expense of students' expression of their own 
responses. [19, p.65] Bill Corcoran and Emrys Evans showed how traditional teaching and criticism of literature viewed these three elements: the literary text was considered either as part of F. R. Leavis's (1895-1978) Great Tradition or as T. S. Eliot's (1888-1965) autonomous artifact; the teacher was put in the role of the custodian or informed explicator; and the student-reader was considered a sort of tabula rasa. [20, p.2]

In reaction to the premises of the biographical-historical approach, which focused on the life and times of the author, New Criticism ${ }^{5}$ studied the text in isolation, focusing on the form and objectively analyzing the work's genre, structural patterns, and language. The New Critics emphasized that the structure of a work could not be divorced from its meaning, viewing the two as constituting a quasiorganic unity. They held the meaning of the text as accessible only to the trained eye of the reader. "Close reading" was presented as the basic mode of reading literary texts: the text takes its distinctive character from its internal relationships. They introduced some famous principles and terms that changed many notions in literary studies. The principle of "affective fallacy" challenged the notion that the reader's response is relevant to the meaning of a work. Another important concept was "intentional fallacy" which challenged the notion that the author's intention determines the work's meaning. Such concepts along with the belief that the meaning of a text can be known objectively, qualified the New Critical approach to be called an "objective" approach to literature. However, this objectivity led to the neglect of the readers' individuality. They postulated what Young calls "a universal reader" free of the human characteristics of personality, social background, and a life lived in time and space. [18, p.9]

New Criticism was widely accepted not only as a critical approach but also as a mode of reading in literature education. It succeeded the liberal-humanist tradition associated with literature education

\footnotetext{
${ }^{5}$ New criticism received its name from John Crowe Ransom's 1941 book The New Criticism. Its foundations were laid in books and essays written during the 1920s and 1930s by I. A. Richards (Practical Criticism, 1929), William Empson (Seven Types of Ambiguity, 1930), and T. S. Eliot ("The Function of Criticism," 1933). The approach was significantly developed later by a group of American poets and critics, including Cleanth Brooks, John Crowe Ransom, Allen Tate, Robert Penn Warren, and William K. Wimsatt. See Bertens, Literary Theory, the chapter on "Reading for Meaning," Newton, Interpreting the Text, the chapter on "The New Criticism and the Rise of Interpretation," and Selden and Widdowson, A Reader's Guide to 
since the establishment of English literature as a reputable study in schools, as a result of the work of Matthew Arnold (1822-88). In a series of essays between 1852 and 1882 on literary criticism and education, Arnold argued for the importance of literature education and its civilizing influence on the nation. Thus, English literature was introduced into the school curriculum on the hope that literature could socialize and humanize people. Arnold emphasized the centrality of the text: literary texts were to be regarded as cultural artifacts that exist as repositories of knowledge. The New Critics took the idea of the autonomy of the text and its centrality to the literary experience as their starting point. However, they refined Arnold's perspective by excluding what they called "extraneous elements." [18, pp.8-9]

New Criticism revolutionized literary studies and education with its new way of reading. For more than fifty years, starting from the late 1920s and well into the 1970s, practical criticism based on New Critical "close reading" became the new common sense. ${ }^{6}$ It gained dominance among college and university faculties [21, p.xi], and at least two generations of American students and many Europeans were affected by that tradition. [22, p.120] Most English teachers were educated in a literary critical tradition that held "practical criticism" as the basic mode in reading and teaching literature. [20, p.1] In their survey of the different theories of reading, Carter and Long show how practical criticism was a very influential practice in the teaching of literature in many parts of the world. They show how it became a valuable approach to the words on the page and to the verbal particularities of specific texts. Close reading was presented as a pedagogical approach that works well not only with small groups, where there can be intensive question and answer sessions, but also in more formal contexts such as a lecture, where the teacher can present his or her own close reading of a text classrooms. [23, pp.150151] Later, New Criticism was superseded by newer critical approaches; however, it continued to hold sway in the majority of literature. [24] 
Many reasons can account for this acceptance and adherence to the principles of New Criticism: what David Bleich calls "the onrush of formalist exegetical criticism." [2, p.95] John Clifford ascribes the way New Criticism became enormously popular among teachers of literature to the "accessible pedagogy" it had, expressed clearly and appealingly in Brooks and Warren's Understanding Poetry. [25, p.7] ${ }^{7}$ Russell A. Hunt explains why they, teachers of literature, welcomed New Criticism while explaining the different modes of reading Jonathan Swift's Gulliver's Travels:

At the time, most of us who were teaching undergraduate courses in eighteenth-century literature thought the results were pretty much all to the good. Now, we thought, we could ask our students to read Gulliver in the faith the text would make everything clear if only we all just read it hard enough- we wouldn't have to go through that long, distracting, boring period of preparation, of filling in historical and social background, before our students would be "ready" to read Swift. [26, p.109]

Hunt also shows how this new mode of reading helped teachers to focus their attention on different kinds of passages in the same texts they used to teach or on completely different works. Milton's poetry, for example, was replaced with Donne's as the central work of the seventeenth century and passages or works concerned with philosophy were gradually replaced by ones concerned with aspects of the text. He ends his explanation citing William Dowling saying that the New Critical pedagogy "appeared to scholars and teachers of [his] generation as a kind of classroom salvation." [26, p.109] The huge expansion of the student population in the United States in the years following World War Two represented a challenge that only New Criticism, with its practical criticism basis, could cope with masses of individuals who had no history in common. [27, p.14] Later, this "pedagogical power" made it difficult for any alternative approach to displace the New Criticism. [28, p.30]

${ }^{7}$ Understanding Poetry was an influential American college textbook and poetry anthology by Cleanth Brooks and Robert Penn Warren, first published in 1938. The book influenced New Criticism and went through its fourth edition in 1976. 
Scholars and teachers found in New Criticism something more than a new critical method for reading literary works. The new approach initiated the "professionalization" of literary studies. [29, p.20] In outlining the history of teaching literature as a discipline in Professing Literature: An Institutional History (1987), Gerald Graff shows how the discipline was searching for a distinct identity and projection as a profession. [2, p.95] It was felt that, for literature to exist as a discipline, it had to appear more scientific and grounded on methodology. [7, p.140] New criticism was a major part in this professoriate's search with its new scientific analytical approach. It represented the scientific and professional spirit of those times, a spirit distinguished by a skill-centered specialization. ${ }^{8}$ Thus, the New Critics were regarded as the proponents of "professional criticism." [27, p.12]

\subsection{The Reader Response Approach.}

The second half of the twentieth century witnessed a new trend in critical and literary thinking. This trend included various theorists who, despite many fundamental differences among them, share a mutual interest in the reader of the literary work as well as in the process of reading. Never before has the reader attained such a prominent position in critical thinking. Terry Eagleton arranges the history of modern literary theory into three stages: "a preoccupation with the author (Romanticism and the nineteenth century), an exclusive concern with the text (New Criticism) and a marked shift of attention to the reader.” [30, p.64] As Peter Rabinowitz says, one can hardly find a serious literary theorist who does not, in one way or another, feel the need to account for the activity of the reader. [31, pp.81-82] The outcome of this new interest in the reader, which some prefers to call an "orientation" not a "method" or a "position," came to be known as the "reader-oriented theories." This term is used to include all the theorists and studies that take into account both the reader and the process of reading. 
Many reasons converged to put this change into force. A minor reason can be found in the increasing focus on the role of the percipient as a result of modern communication theories. However, the main reason can be traced back to the prevailing dissatisfaction with old methods and the search for new ones. [32, p.8] This trend was a reaction against the "New Critical autonomy." [33, p.198] The concern with the reader appeared to "fill the void created by the collapse of a basic New Critical premise that a literary text is an autonomous object that can and should be analyzed without regard to its context." [31, p.82] Clifford illustrates this situation in terms of pervasive distrust of authorities of all sorts that led academics first to a skepticism about, and then a rejection of rigidly constructed systems of official policy in government and in the university:

The old ways just would not serve any longer; consequently, traditional notions of reading and meaning were intensely problematized. Eventually, the a priori authority of the text became widely suspect, and the way was thereby open for thinking hard about how reading actually proceeds. All of this foreshadowed the rejection of formalism ... $[25, \mathrm{p} .2]$

A paradigm shift, similar to that shift in the field of literary criticism, occurred in the teaching of literature away from viewing the text as authority in the hand of the teacher to a view that focuses on the reader's relationship with the text. [34, p.71] The turning point in this shift was the conclusions of the Dartmouth Seminar, the Teaching of English Seminar held in 1966 in Dartmouth College. The representatives of the United States in this seminar, among fifty English educators from Britain and Canada, were startled by the serious doubts cast on the direction taken by the Project English Centers that directed literature curriculum in their country. They found a completely different philosophy current at that time in England. Since Sputnik crisis, those centers imposed high standards of scholarship and intellectuality as a desired outcome of literary pedagogy. The British, on the other hand, were concerned with making the literary work personally significant to the students; in other words, they were 
"encouraging students to respond to the literature read rather than having them analyze it." [35, pp.200203] John Dixon summarized the main ideas presented in this seminar in Growth Through English saying:

The essential talk that springs from literature is talk about experience-as we know it, as he [the student] sees it (correcting our partiality and his; exploring the fullness of his vision, and ours). Conversely, only in a classroom where talk explores experience is literature drawn into the dialogue-otherwise it has no place. The demand for interpretation —was it this or that he meant? —arises in the course of such talk: otherwise it is a dead hand. ${ }^{10}$

Thus, in the late 1960s and the 1970s, teachers began to question the dominant approaches as they felt a lack of fit between the way they were reading literature and the way they were teaching it. They began to feel more responsible for the literary experience of their students. Therefore, that time witnessed the proliferation of the reader response ideas and teachers of literature felt a need to change classroom practice to accommodate the insights offered by the reader-oriented theories. ${ }^{11} \mathrm{~K}$. M. Newton noticed that, in theory, the emergence of the ideas of the New Criticism promised a more active role for the student. The criterion for an authentic reading should be a coherent interpretation of the text that is shaped in a dialogue between teacher and student. However, in practice, the New Critics tended to make disciples rather than share in dialogues. [28, p.30] The teaching procedures of practical criticism were, as Carter and Long highlight, "tightly controlled by the teacher, either in the form of directed questions accompanied by teacher-led commentary, or in the form of a demonstration exposition in a lecture or seminar." [23, p.151] Teachers began to see how the students were not helped in any way to discover and implement for themselves the procedures to come to critical insight.

\footnotetext{
${ }^{10}$ Quoted in [35, p.201).
} 
In 1977, the University of Buffalo convened the Colloquium on "Reader-Response to Literature." This Colloquium "marked the official acceptance of the reader-response approach to the teaching of literature, which has since been taught in the education departments at colleges and universities across the United States." [34, p.71] In 1985, the papers presented in the colloquium were published by Charles Cooper in Researching Response to Literature and the Teaching of Literature: Points of Departure. Cooper states that the book explores the theories and methodologies that help us to learn more about readers affirming that it will be of interest to a variety of audiences including teachers of literature. He organized the book into three parts: theories of response, ways to study response, and ways to study classroom instruction in literature. [36]

\section{Teaching Literature/Theorizing about Literature: Rosenblatt Bridging the Gap}

Louise M. Rosenblatt (1904-2005) is one of the rare literary theorists who developed their ideas in the light of classroom practice and directed these ideas for a more fruitful classroom teaching experience of literature. Although it was but late that she had her real stance as a literary theorist among the pioneers of the Reader Response Approach, she is now hailed as one of the courageous scholars who ventured to gap the split between studying literature and theorizing about literature. Her two books, Literature as Exploration (1938) and The Reader, the Text, the Poem: The Transactional Theory of the Literary Work (1978), presented ideas that were later so influential in literary theory and pedagogy.

Literature as Exploration presented powerful ideas that were many years ahead of its time. The aim of the book was to prove that the study of literature was one of the especially important social and cultural aspects in the life of a democracy. She presented new concepts of the function of literature, the reader, the text, and the process of reading. She showed literature's multiplicity of powers; along with its main function, giving pleasure, the literary work fosters a sounder understanding of life and nourishes the development of balanced, humane personalities. To arrive at these goals, she gave the teacher the task of ministering to the love of literature, and central to this task was the concept that any knowledge 
about literature was useless unless it led the student primarily to seek from the literary work a vital personal experience.

Rosenblatt intended to sketch a theory of the literary experience as the springboard for a philosophy of teaching. Reading a literary work was presented as an "experience" in which "the reader brings to the work personality traits, memories of past events, present needs, and preoccupations, a particular mood of the moment, and a particular physical condition." The text became "merely ink spots on paper" waiting for the reader to transform them into a set of meaningful symbols. The process of understanding a work implied a recreation to it. [37]

After the publication of the first edition of Literature as Exploration, Rosenblatt found in Dewey and Bentley's book Knowing and the Known (1949) the best term that could describe her concept of the relationship between the reader and the text that she had been describing: "transaction." Reading as a transactional process assumes the essentiality of both the reader and the text in creating the meaning of the literary text. She refused to consider the reader as a static entity and the text as something with an already fully-formed meaning; rather, she described reading as a "transaction," during which both the reader and the text continuously affect each other and meaning happens in this transaction. She started to use this concept as it helped her to develop her initial ideas about the process of reading a literary work into a theory of reading known as "the transactional theory of reading literary texts."

In The Reader, the Text, the Poem: The Transactional Theory of the Literary Work (1978), Rosenblatt explicated this theory. The second book was a continuation of the first, but with a different strategy:

Eschewing further educational themes [like those in Literature as Exploration], I concentrate [in The Reader, the Text, the Poem] on presenting a matured and more fully developed theory of the literary work of art and the implications for criticism. [38, p.xii] 
Rosenblatt's transactional theory clearly demonstrates that no one can read the literary work for someone else. She did not consider the literary work, for which she used to refer to as "the poem", an ideal entity or an object; it is an event in time that happens during "the coming-together of the reader and the text at an especially propitious moment." The reader brings to the text past experiences and personal traits; under the effect of the text, the reader "crystallizes out from the stuff of memory, thought, and feeling a new experience", which is the poem. This becomes part of "the ongoing stream of the life experience" of the reader. Reading a work of literature, she believes, is completely different from reading another kind of written communication like a newspaper article. The event that produces the reading of a poem differs from other reading-events. She also illustrated the implications of this concept of transactional analysis of literature for the educational system. The primary concern should be the development of the individual's capacity to live fully and personally in the literary transaction. [38, pp.12-23-36-157]

Three main concerns are recurrent in all Rosenblatt's writings: democracy, reading, and literature education. They were so interrelated in her thinking as she kept highlighting the points of union among them all the time. Rosenblatt did her best to find the point of union between teaching literature and enhancing the values of the democratic society. The democratic role she imagined for literature hinged on the fact that the enhancement of these values depended on the intensification and enrichment of the individual's aesthetic experience. [2, p.91] In her theory, the teacher represents "a catalyst of discussion" in the class; not an authority representing the meaning and background of the literary work. The main role is to encourage a "democracy of voices", express preliminary responses to the text and build group and individual understandings. Teaching literature, as is presented in her writings, fosters attitudes and social relations that can lead to a critical literacy that is imbedded in the values of democracy. [39, p.23]

For Rosenblatt, reading was a vital means in advancing the values of the democratic society. She argued that analysis should be directed to real, not hypothetical, readers. She found it impractical to 
construct ideal reading models to teach students how to read literature. [38, p.138] She was interested in what happened when particular people read a particular text at a particular moment in time. [37, p.35] However, she was not concerned with analyzing the readers' psyches, but with the way they become self-aware, self-critical and self-enhancing as a result of reading the text. [1, p.20] The process of reading was an "exploration," as the title of her first book suggests. She refused to deal with the reading process as an interaction that takes place between two predefined entities: a text and a reader. She believed in the transactional nature of reading in which both the text and the reader were transformed as a result of the reading process. This 'transactional' model of the reading process

... underlies the essential importance of both elements, reader and text, in a dynamic reading transaction. A person becomes a reader by virtue of his activity in relation to a text, which he organizes as a set of verbal symbols. A physical text, a set of marks on a page, becomes the text of a poem or of a scientific formula by virtue of its relationship with a reader who thus interprets it. [38, p.18]

Far from being conceived of a passive process of absorption, the reading process became in her writing an "intense personal activity" and a "medium of exploration." [37, p.viii]

Rosenblatt was convinced that public education was so essential in creating the necessary audience for literature. An audience that could be open and receptive as well as critical and able to connect the writer's vision to their private concerns. [39, p.30] She was shocked to find that the practice in the literature classroom was completely repressive of the students' personal experience with the texts they study; texts were treated as a body of knowledge for informative questioning. Such practice alienated students from reading literature. [25, p.4] She saw in literature inherent potentialities to enhance the values of a democracy. In explaining how a literary experience can be the type of educational process that a democracy needs, she says, 
As the student vicariously shares through literature the emotions and aspirations of other human beings, he can gain heightened sensitivity to the needs and problems of others .... he can develop an imaginative capacity to grasp the meaning of abstract laws or political and social theories for actual human lives. Such sensitivity and imagination are part of the indispensable equipment of the citizen of a democracy. [37, p.274]

Rosenblatt wanted to bring about that change by explaining the theoretical basis of what was going on inside the classroom. She started to question the assumptions of the traditional approaches to teaching literature in the light of her literary theory. The pedagogical implications in her theory are numerous; moreover, in the light of the application of her theory in the classroom, she modified and retheorized many aspects of her theory. [3, p.50] She was after "a broader theory of literature, learning, and instruction" that will help to realize the potentialities of literature education. [4, p.63] Teachers can help students make more out of their transaction with literary works, but they could not do that without being able to reflect more deeply on the dynamics of reading. [5, pp.39-40]

When Rosenblatt's ideas and writings first appeared in the 1930s, they were at odds with those of her time. She wrote her first book, Literature as Exploration, at a time when she felt democracy, as a way of life, was being threatened. [40] Her contention that literature had democratic potentialities was faced with the fact that traditional teaching and criticism of literature frustrated these potentialities. She believed that traditional teaching and criticism of literature were based on faulty assumptions about the nature of reading and the aesthetics of literature. [37, p.xvi] This made her sound revolutionary and out of the beaten critical path. [41, p.171]

Rosenblatt was presenting something completely different at a time the New Criticism was the dominant approach to the study and the teaching of literature. Rosenblatt's book Literature as Exploration was published the same year Brooks and Warren published Understanding Poetry (1938), the book that effectively launched New Criticism. [2, p.95] That was the time the New Criticism was 
gaining much publicity among the scholars and the students of literature. Rosenblatt sounded like "some kind of subversive," as Stephen Dunning describes his initial reaction to his first reading of Literature as Exploration in 1951. Dunning was both "excited and surprised that anyone dared to raise questions about the New Criticism.” [42, p.47] These questions did not address certain concepts or applications; rather, they were an "epistemological break" with the reading theory of the New Critics. [25, p.12] Bill Corcoran attributes this break to the big difference between Rosenblatt's expressionist outlook and the New Critical objectivism. [43, p.154] In opposition to the text based literary theory of the New Criticism, Rosenblatt emphasized the reader's aesthetic response pioneering, ${ }^{12}$ in her first book, the first theoretical work that outlined a reader-oriented approach to the study of literature. [44]

Rosenblatt acknowledged this powerful presence of the New Critics. She referred to the "the postwar glorification of science, fueled by fear of Soviet scientific superiority" that was the main reason for the success of Brooks and Warren's Understanding Poetry [37, p.289] and the "postwar, postSputnik intellectualism"13 that cultivated "the extraordinary dominance of the New Critics in university and critical circles." [38, p.xii] She was aware of the big difference between their writings and her approach although both of them might have seemed to be starting on the same path: "deploring the neglect of literature as an art resulting from the traditional preoccupation with literary history and the message of the work.” [37, p.289] She did not deny her sympathy with their concern for formal values and her admiration of their analytic skills. However, she did not accept their understanding of the nature of art: "I rejected the notion of the poem-as-object, and the neglect of both author and reader, bred by their point of view." [38, pp.xii-xiii]

\footnotetext{
${ }^{12}$ Kenneth Donelson names some teachers and critics who hinted at some points related to the gap between literature and its readers before the publications of Literature as Exploration. [53, pp.11-12]

${ }^{13}$ The Sputnik program was a series of unmanned space missions launched by the Soviet Union in the late 1950 s. The surprise launch of Sputnik 1 as the world's first artificial satellite by the Soviets on October 4, 1957 shocked the United States. This led to major changes in the U.S. Government spending
} 
Writing from a completely different point of view, Rosenblatt's work suffered a great deal of neglect among critics and literary theorists. When Literature as Exploration was published, a reviewer in The New Republic, 29 Jun. 1938, offered this comment:

A really important book, in spite of its insipid title. Writing chiefly for teachers of highschool and college English, the author has managed to show the relevance of social science to the esthetic experience, and vice versa, in a way as yet unequaled [sic] by some of our best Marxists. ${ }^{14}$

This shows how the progressive context of what Clifford calls "the politically sophisticated thirties" [25, p.3] could have sympathized with Rosenblatt's position expressed in the preface of her book: "My aim in this book is to demonstrate that the study of literature can have a very real, and even central, relation to the points of growth in the social and cultural life of a democracy." [37, p.vii] David Bleich is credited as one of the first to pay due attention to Rosenblatt's work. Suleiman concluded the footnote to her introduction with a very important remark: "[Rosenblatt's] relevance for literary theory was recognized only recently, when it was rediscovered by Bleich and others.” [45, p.45] In Subjective Criticism (1978), Bleich, as Carolyn Allen reports, discussed Rosenblatt's early work in more depth, but he criticized her for being moral and pragmatic rather than theoretical. [1, p.15]

If Rosenblatt's work was relegated to a marginal position in literary criticism and theory, it has been a vital guide in another discipline: literary pedagogy. Her ideas on the connection between democracy and literature and the benefits of a response-oriented pedagogy have been important themes for progressive education professors and a number of high school teachers for decades. [25, p.8] Both Literature as Exploration and the NCTE 1939 presentation introduced Rosenblatt as a vital and valued guide among some secondary and elementary school teachers. They persisted in their interest in her 
approach at a time the New Criticism was in dominance in the field of reading and teaching literature both in schools and the university. [46, p.159] Clifford was one of those teachers who were trained as "close readers." They were socialized to believe that "associating one's reading with the actual world, or worse, with one's passionate inner life, was emotionally self-indulgent, solipsistic, and unscholarly." [25, p.2] Leila Christenbury was also one of those teachers-to-be "reared on this tradition;" however, when they became teachers, they found that the technique did not often "translate well." They discovered that the students were "struck dump at the prospect of close, analytical reading divorced from personal or historical context." Many teachers repelled at the way literature was a task not a connection to life. They, therefore, welcomed the reader-response approaches out of their failure to entice the students to celebrate the great craft of literature. [47, p.34]

In the field of teaching literature, Rosenblatt's theory was the source of these insights since the 1960s. [7, p.152] It was in the background of most of the innovative work in critical theory that was associated with the teaching approaches. [34, p.77] She provided teaching as a profession with "the necessary critical and ethical apparatus for reading texts." [25, p.5] She was the best to explicated reader-response ideas as a pedagogical as well as a critical stance. [8] In 1968, the second edition of Literature as Exploration marked the start of acknowledging Rosenblatt's contributions. In his Foreword to that edition, James R. Squire credited the book with being one of the very few books on the teaching of English that he believed all teachers should read. ${ }^{15}$

By the mid1980s, Rosenblatt's position as a shaper of literature education was established. The NCTE 1988 convention was dedicated to her. It featured a symposium that marked the $50^{\text {th }}$ anniversary of the first edition of Literature as Exploration. The articles, published later in Farrell and Squire's Transactions with Literature: A Fifty-Year Perspective for Louise Rosenblatt (1990), demonstrated her extraordinary influence on the teaching of literature, and the educational research in general. [48, p.vii] 
The same year, the fall issue of Reader, "On Louise M. Rosenblatt," was dedicated to essays acclaiming Rosenblatt's half century of importance. Most of the articles in this issue were later revised and published along with other articles in John Clifford's The Experience of Reading: Louise Rosenblatt and Reader-Response Theory (1991). In 1992, Probst showed how the publishers of major textbook series were beginning to try to take Rosenblatt's ideas into account as they design their programs. He wonders how teachers claim that they only started to know how to teach literature for ten or twenty years while the reasonable and comprehensible principles for guiding teaching have been there for fifty years in Literature as Exploration. [35, p.64]

Rosenblatt has been recognized as an influential figure in the teaching of literature, and increasingly have her contributions been recognized in several major publications. Karolides's book that investigated the application of the reader-response approach in teaching shows how of many teachers were interested in reader-response criticism. He holds Rosenblatt's theory as "soundly expressive of each aspect of response-centered critical theory" and "pedagogically the most meaningful for teachers." [21, p.xi] This made her "the most commonly cited figure in the teaching of literature." [34, p.76] Church goes further to claim that

Just as major aspects of the twentieth century have often been described according to Freudian, Jungian, Einsteinium or Vygotskian theories, a review of the literature reveals that Rosenblatt has been frequently cited as a similar authority in the teaching of literature.

In his Foreword to the fifth edition of Literature as Exploration (1995), Wayne Booth doubts that any other literary critic has "enjoyed and suffered as sharp a contrast of powerful influence and absurd neglect as Louise Rosenblatt." On the one hand, no other critic has such an influence on teachers and how they read and teach literature. On the other hand, those working in literary criticism and theory started to acknowledge the "relevance of her arguments" only recently. He wonders, "How many other 
critical works first published in the late thirties have extended themselves, like this one, to five editions proving themselves relevant to decade after decade of critical and pedagogical revolution?.” [49, p.vii]

\section{Conclusion.}

The first section of this paper gauged the split in the profession of "English Studies" between studying literature in scholarly work that investigates the nature of literature and the methods of reading and analyzing literary works, and teaching literature in classroom that takes all this theorizing about the nature of literature and the methods of reading and analyzing literary works into practice. This section surveyed the analyzed experience of some famous scholars in the profession who have tackled, and sometimes complained of, this issue in their writings. The outcome of this analysis leads to a very obvious conclusion that there is some neglect in the part of people specialized in literary studies of the practical side of their work, and, at the same time, there is a similar neglect in departments that teach literature of preparing their graduates on methods of teaching literature. It is highly recommended, then, that professors of literature make teaching of literature one of their academic interests and part of their work; in addition, students of literature who are supposed to get into the market of teaching should have good preparation on how to teach literature.

The other two sections concentrated on the points of convergence between literary pedagogy and literary theory. The first one presented two cases in which literary pedagogy was highly influenced by the ideas of two major shifts in critical theory: the formalist tendency of New Criticism and the readeroriented tendency of the reader response approach. The outcome of this presentation leads to the conclusion that what literary theorist present as methods for analyzing literary works lay the foundations upon which much classroom practice is conducted. However, there should have been another conclusion that the teaching situation provides literary theorists with a good context for deriving and applying their critical theories. This aspect, surprisingly, is proved to be lacking in literary studies as a result of the neglect pinpointed earlier. Hence, the other section discussed in detail the efforts of Louise Rosenblatt in 
providing a theory of reading literary works in the light of what takes place in literature classrooms. The outcome of this discussion is that Rosenblatt proved to be one of the rare scholars who took literature teaching seriously while presenting valuable theoretical ideas about literature. It is highly recommended, then, that Rosenblatt's experience to be taken into consideration and literary theorists pay due attention to what goes on in literature classrooms before, while and after they hypothetically present ideas about methods of reading and analyzing literature. 


\section{References}

[1] Allen C. Louise Rosenblatt and Theories of Reader-Response. In [54, pp.15-22]

[2] Willinsky J. The Lost Reader of Democracy. In [54, pp.85-103]

[3] Salvatori M. On Behalf of Pedagogy. In [54, pp.47-62]

[4] Applebee AN. Fostering Literary Understanding: The State of the Schools. In [55, pp.59-63]

[5] Evans E. Readers Recreating Texts. In [56, pp.22-40]

[6] Levine GL. The Two Nations. Pedagogy. 2001;1 (1): pp.7-19.

[7] Crockett AJ. Nonfiction and Fiction: Does Genre Influence Reader Response? Dissertation. Digital Library and Archives, The Virginia Polytechnic Institute and State University. 1998 (cited 1 Feb. 2017). Available from:

https://vtechworks.lib.vt.edu/bitstream/handle/10919/25990/dissertation.pdf?sequence=1\&isAllowe $\underline{\mathrm{d}=\mathrm{y}}$

[8] Pugh SL. Teaching Children to Appreciate Literature. ERIC: Clearinghouse on Reading and Communication Skills. 2005 (cited 11 Nov. 2015). Available from: http://www.vtaide.com/png/ERIC/Appreciate-Lit.html

[9] Robertson DW, Martin DK, Singer PA. Interdisciplinary Research: Putting the Methods under the Microscope. BMC Medical Research Methodology. 2003 (cited 1 Feb. 2017). Available from: http://www.biomedcentral.com/1471-2288/3/20

[10] Burk DS. Literature in an Interdisciplinary Unit. The ALAN Review. 1996; 23 (2). Digital Library and Achieve. 1996 (cited 2 Feb. 2015). Available from: http://scholar.lib.vt.edu/ejournals/ALAN/winter96/burk.html

[11] Bérubé M. The Employment of English: Theory, Jobs, and the Future of Literary Studies. New York: New York University; 1998.

[12] Frye N. The Anatomy of Criticism: Four Essays. New Jersey: Princeton University Press; 1957.

[13] Hawkins P. Frye in the Classroom: Teaching Shakespeare with Northrop Frye and Harold Bloom. ESC: English Studies in Canada. 2011;37: pp.131-136.

[14] Tompkins J. Pedagogy of the Distressed. College English. 1990; 52 (6): pp.653-660.

[15] Showalter E. Teaching Literature. Australia: Blackwell; 2003.

[16] Anderson PM, Rubano G. Enhancing Aesthetic Reading and Response. Illinois: NCTE; 1991.

[17] Karolides NJ. The Transactional Theory of Literature. In [57, pp.21-32]

[18] Young C. Readers, Texts, Teachers. In [56, pp.7-21]

[19] Beach R. Transactions with Literature: A Fifty-Year Perspective for Louise M. Rosenblatt. In [55, pp.65-77]

[20] Corcoran B, Evans E. Introduction. In [56, pp.1-6]

[21] Karolides NJ. Preface. In [57, pp.xi-xii] 
[22] Purves AC. The Aesthetic Mind of Louise Rosenblatt. In [54, pp.209-217]

[23] Carter R, Long MN. Teaching Literature. London: Longman; 1991.

[24] Molinelli PM. The Significance of Stance: An Invitation to Aesthetic Response. Proceedings of The National Reading Conference; 1995; New Orleans, LA: ERIC: Education Resources Information Center. 1995 (cited 2 Feb. 2015). Available from: https://eric.ed.gov/?id=ED404615

[25] Clifford J. Introduction: Reading Rosenblatt. In [54, pp.1-14]

[26] Hunt RA. Modes of Reading, Modes of Reading Swift. In [54, pp.105-126]

[27] Selden R, Widdowson P. A Reader's Guide to Contemporary Literary Theory, 3rd ed. London: Harvester; 1993.

[28] Newton KM. Interpreting the Text: A Critical Introduction to the Theory and Practice of Literary Interpretation. London: Harfester Wheatsheaf; 1990.

[29] Bertens H. Literary Theory: The Basics. London: Routledge; 2001.

[30] Eagleton T. Literary Theory: An Introduction. Oxford: Blackwell; 1983.

[31] Rabinowitz P. Whirl Without End. In Atkins GD, Morrow L. Contemporary Literary Theory. London: Macmillan; 1989. pp.81-100.

[32] Holub RC. Reception Theory: A Critical Introduction. London: Methuen; 1984.

[33] Crasnow E. Reader. In Fowler R. A Dictionary of Modern Critical Terms. London: Routledge; 1987. pp.197-99.

[34] Church GW. The Significance of Louise Rosenblatt on the Field of Teaching Literature. Inquiry. 1997; 1 (1): pp.71-77.

[35] Probst RE. Reader Response Theory and the Problem of Meaning. Publishing Research Quarterly. 1992; 8: pp.64-73.

[36] Cooper CR. Researching Response to Literature and the Teaching of Literature: Points of Departure. Greenwood: Praeger; 1985.

[37] Rosenblatt LM. Literature as Exploration. 3rd ed. London: Heinemann; 1970.

[38] Rosenblatt LM. The Reader, the Text, the Poem: The Transactional Theory of the Literary Work. Illinois: Carbondale and Edwardsville; 1978.

[39] Pradl GM. Reading Literature in a Democracy: The Challenge of Louise Rosenblatt. In [54, pp.2346]

[40] Marinaccio P. Louise Rosenblatt Interview: Distinguished Visiting Scholar Department of Teaching and Learning, School of Education, University of Miami. 1999 (cited 7 Mar. 2015) Available from: http://www.education.miami.edu/ep/rosenblatt

[41] Bressler CE. Literary Criticism: An Introduction to Theory and Practice. 2nd ed. New Jersey: Prentice Hall; 1999.

[42] Dunning S. Exploring a Poem. In [55, pp.47-56]

[43] Corcoran B. From Transaction to Resistance: An Antipodean Journey. In [54, pp.147-163] 
[44] Imtiaz S. Rosenblatt Revisited: Roles of Form, Text, and Reader in Creative Literature. Language in India. 2004 (cited 22 Feb. 2018). Available from: http://www.languageinindia.com/june2004/shaguftarosenblatt.html

[45] Suleiman SR. Introduction. In Suleiman SR, Crosman I. The Reader in the Text: Essays on Audience and Interpretation. Princeton: Princeton University Press; 1980. pp.1-45.

[46] Karolides NJ. Theory and Practice: An Interview with Louise Rosenblatt. Language Arts. 1999; 77 (2): pp.158-159.

[47] Christenbury L. The Guy Who Wrote This Poem Seems to Have the Same Feelings as You have: Reader-Response Methodology. In [57, pp.33-44]

[48] Farrell EJ, Squire JR. Preface. In [55, pp.vii-viii]

[49] Booth W. Foreword. In Louise M. Rosenblatt. Literature as Exploration. $5^{\text {th }}$ edition. New York: MLA; 1995. pp.vii-xiv.

[50] Bishop RS. Fifty Years of Exploring Children’s Books. In [55, pp.1-9]

[51] Regan S. Reader-Response Criticism and Reception Theory. In Eliot S, Owens WR. A Handbook to Literary Research. London: Routledge; 1998. pp.139-49.

[52] Roen D, Karolides NJ. Louise Rosenblatt: A Life in Literacy. ALLAN Review. 2005 (cited 3 Jun. 2006). Available from: http://www.findarticles.com

[53] Donelson K. Fifty Years of Literature for Young Adults. In [55, pp.11-18]

[54] Clifford J. The Experience of Reading: Louise Rosenblatt and Reader-Response Theory. Portsmouth: Boynton/Cook; 1991.

[55] Farrell EJ, Squire R. Transactions with Literature: A Fifty-Year Perspective for Louise M. Rosenblatt. Illinois: NCTE; 1990.

[56] Corcoran B, Evans E. Readers, Texts, Teachers. Portsmouth: Heinemann; 1987.

[57] Karolides NJ. Reader Response in the Classroom: Evoking and Interpreting Meaning in Literature. New York: Longman; 1992. 